fundamental principles of democratic government. Insofar, however, as the derogation of the rights of citizens is permitted to become a tool for the oppression of minorities and the suppression of the "hostile" opposition, the changing standards would seem to be in retreat from the principles of democracy. The very institution of enemy hearing boards, which now seems an advance from the old concept of the rightless enemy alien, can become a star chamber for the coercion of recalcitrant citizens in the hands of an administration that is not alive to the responsibility of a fair and objective application of restrictions.

The successful application of criteria based on loyalty rather than citizenship would seem to demand a considerable degree of realism in viewing the world and the war. If hostility is to be determined on an individual basis, the determinors must act on the basis of a clear vision of the difference between disloyalty to the nation and disaffection for the incumbent administration, and must see the war in terms of an instrument of national, rather than partisan, policy. There is no place in such a scheme for legal fictions. The heart of the change is the discarding of the old fiction that any national of the enemy government is per se loyal to the enemy, while any citizen of the home government is per se loyal to the home government. In place of this fictional concept is the realization that-loyalty is a matter of individual men, to be individually determined. If it is to be so determined, the determination must be done afresh in each case, and not from a predetermination that all members of a given racial or cultural group are a priori disloyal.

\title{
PUBLIC CONTROL OF PETROLEUM PIPE LINES
}

THE strategic position of pipe lines ${ }^{1}$ in the petroleum industry derives partly from the importance of transportation in an industry with widely separated producing, refining, and consuming areas. ${ }^{2}$ Thus, California, Texas, and the major producing states in the great Mid-Continent field-Oklahoma, Arkansas, and Louisiana - supplied $73 \%$ of the crude recovered in the United States

1. As used in this article, "pipe lines" refers to "trunk pipe lines," or those which run from field to refinery, or from refinery to market area. "Gathering pipe lincs" rum from wells to entering terminals on the "trunk lines," and the relatively minor problems connected with their operation will not be discussed in this article.

2. The three states of Texas, California and Oklahoma together produced $77 \%$ of the total crude oil of the United States in 1937, but consumed only $16 \%$ of the gasoline. On the other hand, all states east of Indiana, Kentucky, Tennessec, and Georgia produced $3 \%$ of the total crude oil in 1937, but consumed $40 \%$ of the gasoline. See Hearings bcfore the Temporary National Economic Committe Pursuant to Public Resolution No. 113, 75th Cong., 3d Sess, (1939) Chart V facing page 7704 (hereafter cited as TNEC: Hearings). 
in $1941 .^{3}$ Some of the most important markets, on the other hand, are represented by the large metropolitan areas in the north central states and along the Atlantic seaboard. Since some refineries are located in the fields, gasoline pipe lines compete with tank car and truck in taling gas from them to consuming areas. Crude oil pipe lines take oil to another group of refineries located on the Gulf Coast, and the refined gasoline goes in large part by tanker to markets on the Atlantic seaboard. The greatest number of refiners, however, are located in the market areas. They may receive crude by oil pipe lines, ${ }^{4}$ or in the case of refineries located on the East Coast, by a combination of crude oil pipe line from the fields to the Gulf and tanker shipments of crude to the refineries.

The importance of petroleum pipe lines which is derived from the geographical arrangement of the industry is enhanced by the fact that for certain areas pipe lines possess major advantages over the other chief means of transportation - tanker and tank car. The cheapest form of transportation is the tanker; but it cannot be used for many important market regions. Transportation by tank car is much more expensive than by pipe line. The importance of the oil pipe line in the industry can best he demonstrated by the fact that, during each of the years from 1934 to $1937,71, \%$ of the crude oil received at refineries was delivered by pipe line. ${ }^{6}$ While the gasoline pipe line does not play as large a role, relatively, as the crude oil pipe line, its importance is steadily increasing. ${ }^{7}$

Possession of ready access to pipe lines by some companies has necessarily given them a distinct competitive advantage over other firms unable to use the lines on equal terms. The result has been to limit competition in the crude market and in the refinery and wholesale gasoline markets. Concerns in a position to use crude oil lines are enabled to locate their refineries $^{8}$ in the market areas. This arrangement allows more flexible operation since the refiner can shift his purchases of crude as circumstances of supply and price change in the different fields. Less fortunate refiners must usually locate in the fields for two reasons. In the first place pipe line rates and restrictive shipping conditions are such as to force the independent oil producer to sell his

3. Dep't of the Interior, Bureau of Mlines, Monthly Petroleum Statement. No. P219, Dec., 1941. The fields in Illinois, another major producing state, are loeated near the great Chicago market area.

4. As used in this article, "oil pipe lines" refer to lines used for transporting crude petroleum, while "gasoline pipe lines" refer to lines used for transporting gasoline and other petroleum products.

5. Relative costs are tanker, 1.25 mills per ton-mile, pipe line, 3.2 mills per tonmile, and tank car, 8.3 mills per ton-mile. See Cook, TNEC REP., Con:Tror of rHE PEtroleuar Industry by Major Oil Cosrpanies, Monograph 39 (1941) p. 19.

6. See TNEC Hearings at 7719.

7. See id. at 7724,7728 .

8. In most cases, it is the refiner, and not the producer, jobber, or retailer, who ships over the oil pipe line. Oil is customarily bought at the well by the refiner, and he pays for its transportation to his plant. 
crude in the field rather than ship it to market areas. And unless there is an independent refiner located in the field, the sale of crude must usually be to the major owning the pipe line running from the field. ${ }^{\ominus}$ In the second place the refiner is unable to make extensive use of tank car and truck in getting crude from the field to a market-located refinery since they are too costly for the purpose, and tankers, on the other hand, are ustually unavailable. Even when tankers are available, the small refiner may find it impossible to use them because of the high costs of storing and shipping the large amount required as a minimum shipment by the tanker owners. ${ }^{10}$ The refiner located in the field is necessarily tied to the conditions of crude supply and price prevailing in his field. When the field is exhausted, the refiner must go out of business or move; and as new, flush fields, capable of producing a lower-cost crude, are discovered, the field located refiner is necessarily left at a competitive disadvantage as far as the larger markets are concerned. In like manner, access to gasoline pipe lines is of great advantage in allowing the refiner to extend his market beyond the restricted area about the refinery which he can reach by truck or short rail shipments. Gasoline lines arc especially important to field-located refineries, most of which lie far from the major market areas.

Control of oil and gasoline pipe lines is in the hands of the twenty major oil companies. Each of these so-called "majors" is an integrated company, engaging in all phases of the oil industry, production of crude, refining, transportation and marketing. ${ }^{11}$ The twenty majors produce $52 \%$ of the crude oil; they own $87 \%$ of the deadweight tonnage of tankers, and they sell $80 \%$ of the gasoline. ${ }^{12}$ The extent of major company control over pipe lines is demonstrated by these facts: On January 1, 1938, fourteen of these twenty major companies owned $89 \%$ of all crude oil pipe line mileage on which reports to the Interstate Commerce Commission are given. ${ }^{13}$ On the same date, these same fourteen companies owned $96 \%$ of the total gasoline pipe line mileage in the United States. ${ }^{14}$

The majors have used their ownership and control of the pipe lines to prevent the independent refiners from using the lines on equal terms. As evidence that the independents have made little or no use of the lines, the Interstate Commerce Commission found that, in a group of thirty-seven important oil pipe line companies, ten served none but their oil company owners, twenty served from one to six non-owner shippers, while seven served from ten

9. The price of crude is posted by one of the major oil companies in each of the large oil fields and the posted price is usually followed by the other oil companics. Sce TNEC Hearings at 9767, 9943-9945 and Comment (1942) 51 YALE L. J. 608, 621.

10. See Cook, op. cit. supra note 5, at 19.

11. Total assets of these companies amount to nearly nine billion dollars, or sixty percent of the total investment in the entire industry. See $\mathrm{C}_{00 \mathrm{~K}}$, op. cil. supra note 5 , at $\mathbf{3}$.

12. See $i d$. at 5 .

13. The Commission receives reports on approximately $89 \%$ of the total crude oil trunk pipe line mileage in the United States. See TNEC Hearings at 7720, 7723.

14. See id. at 7729 . 
to thirty-seven non-affiliated shippers.15 And, as the Commission pointed out, the non-owner shippers, reported by twenty-seven out of the thirty-seven firms, were in most, if not all, cases other majors. ${ }^{16}$ Perhaps the best evidence that the independent refiners are not using the pipe lines is the fact that the great majority of them are located in the mid-continent oil fields. This was caused largely by the fact that independent refiners could not get access to the oil pipe lines, and, therefore could not locate in the market areas. ${ }^{\mathbf{}}{ }^{17}$

The majors have used their pipe lines to obtain oil in the field at favorable prices and gain a competitive advantage over independent refiners in the market areas, despite the nominal common carrier status of the lines, which should guarantee equality of treatment to all shippers. The techniques by which the majors have accomplished this are, broadly speaking, twofold. The rates charged have usually been greatly in excess of cost of service; and onerous service regulations, centering chiefly around high minimum tender requirements, have been imposed.

Although the majors likewise pay the high rates, they receive back the excess of charges over cost in the form of dividends or profits on their pipe line departments. For them the high rates are wholly a matter of bookkeeping. In addition, they receive the profits made by the pipe line companies on any shipments of oil made by the independents. Thus the majors receive a double rebate.

That pipe line rates are much higher than pipe line costs, including whatever might be regarded as a reasonable return on investment, has been demonstrated many times. Testimony before the Temporary National Economic Committee disclosed that, on one oil pipe line, the rate was 20 cents per barrel, while the cost, including $6 \%$ on the investment, was but 10 cents per barrel. ${ }^{18}$ On another oil line, the rate was $17 \mathrm{y} / 2$ cents per barrel, while the cost was but 5 cents per barrel. ${ }^{10}$ The Interstate Commerce Commission found that, in 1935, 27 of the most important oil pipe line companies averaged a return of $17 \%$ on the final valuations of their property made by the Interstate Commerce Commission. ${ }^{20}$ The Commission said that, "It is evident that the rates charged by the respondents are not made with any relation to the cost of service. . . ."1 A comparison of rates with costs, including $6 \%$ on investment, of a gasoline pipe line running from Tulsa to various cities disclosed the following:22

15. Reduced Pipe Line Rates and Gathering Charges, 243 I. C. C. 115, 121 (1940).

16. See id. at 139.

17. See TNEC Hearings at 8157-\$158.

18. See id. at 7338 .

19. See id. at 7582 .

20. Figures taken from Reduced Pipe Line Rates and Gathering Charges, 243 I. C. C. 115,148 (1940).

21. See $i d$. at 139.

22. Figures taken from Petroleum Rail Shippers' Association v. Alton \& Southern Railroad, 243 I. C. C. 589,616 (1941). In this proceeding, the rates quoted above were drastically reduced. See page 1353 infra. 


\begin{tabular}{lc}
\multicolumn{1}{c}{ City } & $\begin{array}{c}\text { Rate (in cents } \\
\text { per } 100 \mathrm{lbs} \text { ) }\end{array}$ \\
Kansas City, Missouri & 28 \\
Des Moines, Iowa & 36 \\
Chicago, Illinois & 40 \\
Madison, Wisconsin & 46 \\
Duluth, Minnesota & 52 \\
Marquette, Michigan & 63
\end{tabular}

Cost (in cents per $100 \mathrm{lbs}$. and including $6 \%$ on investment) 7
13
19
19
24
27

Statistics compiled by the staff of the Temporary National Economic Committee for the year 1938 disclosed that 15 principal pipe line companies owning $77 \%$ of the net investment in carrier property of all oil and gasoline pipe lines reporting to the Interstate Commerce Commission had an average rate of return of $28 \%$ on investment less depreciation. ${ }^{23}$ All these figures point to the conclusion that pipe line rates are excessively high, when com- pared with pipe line costs, including a reasonable return on investment. During the last few years there have been substantial rate reductions on many pipe lines. ${ }^{24}$ However, it is probable that rates are still much higher than costs on many lines, especially in view of the increase in receipts and revenues of some lines owing to the critical shortage of tankers. ${ }^{25}$

It is, however, argued that the hazards of pipe line ownership justify the high rates of return. A high rate of profit has been defended on the ground that it is impossible to calculate the length of life of an oil field upon which a pipe line depends and that there always exists the possibility that the discovery of better pools may suddenly divert the demand for oil to new areas. Also, that as the pool runs out and the volume of crude declines, per barrel costs will increase. ${ }^{26}$ To compensate for this, there is need for a high rate of return in the early years of operation of a pipe line. On the other hand, it has been suggested that pipe lines might be used for transporting alcohol made from vegetable matter, or liquefied or powdered coal, when they can no longer be used to transport oil or gasoline. ${ }^{27}$ However, in most instances, this whole

23. Those companies which report to the Commission own $85-90 \%$ of the total investment in pipe lines. See TNEC Hearings at 7720.

24. See page 1353 infra.

25. It is not clear from the statements accompanying these statistics on pipe line costs just how overhead costs were handied and how the per-barrel costs varicd with different rates of operation. In Reduced Rates and Gathering Charges, 243 I. C. C. 115 (1940) the Interstate Commerce Commission did record some evidence indicating that overhead costs did not play the dominant role in the make-up of per-barrel costs. Thus while volume of oil transported doubled for one pipe line its unit costs decreased but $11.3 \%$; with another, while volume increased $66.5 \%$, unit cost remained almost the same. $I d$. at 128 . However, the figures covered a range of several years during which costs of various items such as labor greatly increased. It is probable that now with many pipe lines operating at full capacity, per-barrel costs are at a minimum and the disparity between income and cost per barrel is even greater than that shown for peacetime operations.

26. See Beard, Regulation of Pipe Lines as Conmon Carriers (1941) 80.

27. See id. at 170 . 
argument is rather unrealistic since many of the pipe line investments have long since been returned to the stockholders as dividends. ${ }^{28}$ The Interstate Commerce Commission emphasized this fact in Reduced Pipe Line Rates and Gathering Charges ${ }^{29}$ where the Commission issued an order to a large group of important oil pipe line companies to show cause why their rates should not he reduced so as to yield only $8 \%$ on the valuation of their property.

A second reason why independent refiners find it very difficult to utilize pipe lines lies in certain service regulations imposed by pipe line companies. Chief among these service regulations is that of high minimum tender requirements. A minimum tender is a minimum amount which a pipe line will accept for shipment over its lines. Although minimum tender requirements differ greatly with different pipe lines, a typical figure is 50,000 harrels. Such a large minimum tender makes it difficult, if not impossible, for a small, independent refiner to use the pipe lines. ${ }^{31}$. An independent refiner may have refinining capacity of only 2,500 barrels per day. To use the pipe line which has a minimum tender requirement of 50,000 barrels, he must orider enough oil shipped to him to last 20 days. The investment in oil alone, at current prices, ${ }^{32}$ is $\$ 55,500$. In addition, the transport charge from, say the Mid-Continent area to Chicago, is over $\$ 10,000$. Finally, the refiner must

28. Thus in Reduced Pipe Line Rates and Gathering Charges there was evidence showing that two pipelines running from the Mid-Continent field to Illinois were operating at only $25 \%$ of capacity and losing money due to competition from the new Illinuis fields. However, the Commission pointed out that both lines had "returned in dividends to their owners much more than the amount of money invested" in them. Reduccl Pine Line Rates and Gathering Charges, 243 I. C. C. 115, 133 (1940).

29. 243 I. C. C. $115,132,133$ (1940). And in many ases of pipe line compranies which had returned in dividends such a large proportion of their original investment, accrued depreciation charges represented likewise a large fraction of the original investment. The following table shows "for typical pipe lines ouncd by large oil compunics through stock ownership and for one independent company" investment, accrucd depreciation, and "the total dividends paid by each respondent named during the period January 1,1929 , to June $30,1938 . "$

\begin{tabular}{|c|c|c|c|}
\hline & & Alectle & \\
\hline Company & Inecstment & Depreciation & Dizidonds \\
\hline antic Pipe Line $C$ & $\$ 19,300,000$ & $\$ 12, \$ 00,000$ & $\$ 30,900,000$ \\
\hline uckeye Pipe Line Co. & $19,900,000$ & $12,700,000$ & $6,900,000$ \\
\hline Humble Pipe Line Co. .. & $101,300,000$ & $46,400,000$ & $138,200,000$ \\
\hline Illinois Pipe Line Co. ....... & $38,700,000$ & $26,000,000$ & $38,600,000$ \\
\hline rell Pipe Line Corp. . & $55,800,000$ & $27,600,000$ & $101,400,000$ \\
\hline ano & $90,800,000$ & $54,200,000$ & $111,000,000$ \\
\hline
\end{tabular}

(Figures are to the nearest $\$ 100,000$. Id. at 130, 131. The ICC, of course, controls depreciation charges for the common carrier pipe lines.

30. See Cook, op. cit. supra note 5, at 24, and TNEC, Rer. Reriew Axn Comricis:s on Bemalf of Standard Oil Co. (New Jersey) and Sux Olz Co. of Mo:sograpk No. 39 with Rejolnder by MoNograph Author, Monograph 39-A (1941) page 87.

31. See Bearo, op. cit. supra note 26, at 95; TNEC Hcarings at 8291-8340; Petroleum Rail Shippers' Association v. Alton \& Southern Railrosd, 243 I. C. C. 589,657 (1941).

32. See New York Times, Má 24, 1942, p. 5, col. 1. 
build expensive storage tanks at his refinery, and in the oil field, and run the risk of evaporation, fire, and falling prices. Thus, the expense is prohibitive to all but the large, major company refineries. The same analysis is applicable to the small refiner who desires to use a gasoline pipe line.

The evidence as to the necessity of high minimum tenders is conflicting. Various shipments of oil may differ in quality, and if one kind of oil follows another kind through the pipe line, the two may mingle, and thus catuse contamination. The same is true of gasoline. The contention is that the commingling is increased if smaller shipments are conveyed, and that the cost of putting a shipment of oil or gasoline back on specification after it has thus become contaminated justifies high minimum tender requirements. The problem of contamination may, however, have received exaggernted emphasis, since there are means at hand to decrease the amount of contamination. $^{33}$ The defenders of high minimum tenders also argue that there are other expenses which arise from low minimum shipments. ${ }^{34}$ While it is difficult to arrive at a conclusion on a problem so largely technological in character, it would seem that a minimum tender requirement of 50,000 barrels is unnecessarily high. The Interstate Commerce Commission, although not completely convinced, felt that a minimum tender of more than 10,000 barrels was unreasonable on oil pipe lines. ${ }^{35}$

Other service regulations may hamper use of pipe lines by independents. For example, the problem of ratable takings may arise. If the total amount of oil or gasoline sought to be shipped exceeds the capacity of the pipe line, the pipe line company must apportion the amount to be shipped among the various shippers, and it is prohibited from discriminating against any shipper. $^{36}$ There is some evidence, however, which tends to show that pipe lines are not observing their legal obligations. ${ }^{37}$ With the critical situation now existing in transportation of gasoline this problem may become quite significant. ${ }^{38}$

Exclusion of the independent refiner from use of pipe lines has tended to limit competition in the petroleum industry. Because independent refiners cannot use crude oil lines on a competitive basis, they have been forced to locate largely in the fields. As a result, the major companies owning the pipe lines, the chief effective outlets to the large markets, have been able to purchase crude as monopolistic buyers at prices which are lower than they

33. See BEARD, op. cit. supra note 26 , at 97.

34. See Petroleum Rail Shippers' Association v. Alton \& Southern Railroad, 243 I. C. C. 589,657 (1941).

35. Reduced Pipe Line Rates and Gathering Charges, 243 I. C. C. 115, 136 (1940).

36. 24 Stat. 380 (1887), 49 U. S. C. \& 3(1) (1940).

37. See TNEC Hearings at 8156 and $8172-8173$.

38. Other service regulations restricting the use of pipe lines include the requirement of a very narrow range of specifications as to the quality of any shipment which will be accepted. For example, the Sun Oil Company practically restricts shipments of gasoline in its pipe lines to those qualities which are equivalent to "Blue Sunoco". This has the effect of excluding lower grade gasoline produced by many independent refiners. See Cook, op. cit. supra note 5 , at 39 . 
would be if independent refiners could operate on more nearly equal terms. And the necessity for the independent refiners to locate in the fields and their inability to use the gasoline lines on terms approaching equality with the majors has put them at a disadvantage in competing in the big marketing areas. The result has been to give the majors virtually uncontested dominance in the purchasing of crude oil and in the marketing of gasoline in the great consuming areas. Since not all majors compete in any one of the major consuming areas, the number of firms effectively competing in each gasoline market is diminished still further. As is usual in a market where there are only a few large firms competing, the phenomenon of price leadership manifests itself. Each firm realizes that if it were to cut price, each of its competitors would follow suit and the result would be simply the division of the market on the same basis as before but at a reduced level of prices. ${ }^{39}$ Consequently, instead of the independent price policy characteristic of the more competitive market, the various firms tend to follow tacitly the prices set by one of their number usually a larger firm known as the "price leader".

Evidence of price leadership in the gasoline market was furnished by early investigations of the oil industry ${ }^{40}$ and more recently in the Madison Oil case. ${ }^{41}$ In this suit about twelve of the major oil companies, distributing more than $85 \%$ of the gasoline sold in a ten-state mid-western area, were convicted of rigging the gasoline market in violation of the Sherman Act. Taking advantage of a trade practice which based the prices of the large quantities of gasoline sold to jobbers ${ }^{32}$ on the price in the much smaller "spot" 43 market, the defendant majors cooperated in a buying program in

39. It is possible that the elasticity of demand in the market might be such as to result in a greater total money volume of business following the cutting of prices by the few firms in the market. In this case the price reduction would take place. However, in a price leadership market the equilibrium sale price finally reached would still be absve the price set in the same market were it perfectly competitive.

Seemingly the demand for gasoline is relatively inelastic within a certain price range. This apparently is true because the cost of gasoline is a relatively small item needed to make effective the much larger investment represented by a car. See HassiLton, Price and Price Policies (1938) 120.

40. See Burns, The Dechine of Competition (1936) 95 et scq.

41. Socony-Vacuum Oil Company v. United States, 310 U. S. 150 (1940). See Note (1940) 49 YAlE L. J. 761.

42. About $40 \%$ of the gasoline sold in the area was sold under long term contracts with jobbers, who acted as intermediaries between the large refiners and the independent service stations. Almost without exception these contracts provided that the sale price was to be determined at the time the purchase was made by the quotations then current in the "spot" market. United States v. Socony Vacuum Oil Co., 310 U. S. 150 (1940), Record on Appeal, pp. 999-1000, 3031-3042.

43. The "spot market" quotations represented the composite of prices on sales mads by oil field refineries, usually independents, in day to day transactions. These sales amounted to less than $10 \%$ of the gasoline distributed in the ares. During the period bsfore the adoption of the majors' cooperative program, "sput market" prices had basn depressed by the presence in the market of so-called surplus gasoline: that part of the production of independent refiners for which they had no ready customers and which 
the "spot" market designed to buoy up that determining price and thereby raise the price on the sales to jobbers. As wholesale prices to jobbers rose, Standard of Indiana, the area market leader, likewise advanced tank wagon prices $^{44}$ and retail prices at its service stations to maintain a customary fixed margin over the "spot" market price. ${ }^{45}$ No price competition broke out to interrupt the regulated advance. Had price leadership not existed, such a rise in prices through this concerted program would probably have been impossible. Although the overt cooperative buying program was eliminated by the decision in the Madison Oil case, the basic competitive situation has not changed. Price leadership is still characteristic of the refinery gasoline market and, hence, the price for gasoline is higher than it would be in a more competitive market.40

The independent jobber, because of the lack of independent refinery competition in the refinery gasoline market, has become largely dependent upon the majors for his supply of gasoline.47 As a result, some independent jobbers, while retaining a nominal status as independents, are forced to follow major company policies as to wholesale price maintenance. ${ }^{48}$ Others are going out of the jobber business entirely, ${ }^{40}$ and are becoming agents or employees of the majors..$^{50}$ The result of this trend towards major domination of the jobber market will be to decrease still further price competition in sales of gasoline to the dealer.

In the retail field, perhaps the primary competitive consideration for the integrated majors has been the maintenance of the volume of gasoline sold - gallonage. ${ }^{51}$ Maintenance of gallonage even at a loss in marketing operations meant that other departments of the integrated firm would be kept operating. ${ }^{52}$ In this effort to maintain position and to keep their names

they were obliged to sell for what it would bring in the spot market. This distress position of the independent refiners resulted in part from the pegging under the NRA code of the crude price at the very high level of one dollar. Id. at 952-953, 958-959. When the price of gasoline failed to rise proportionately, the independent refiner who had to buy his crude on the market was squeezed. In their program of cooperation the majors eliminated the depressive effect of the low spot market price on the sale price under their long term jobber contracts by jointly buying up the "surplus"gasoline. Note (1940) 49 YALE L. J. 761.

44. The tank wagon price is the price of sales made from the company truck to the service station owner.

45. Id. at $251,252,290,1233-1235$.

46. See Hearings before a Subcommittee of the Committce on the Judiciary on $H$. R. 2318, 76th Cong., 1st Sess. (1939) 25, 125-126, 154 ; TNEC Hearings 7369, 7379.

47. See Hearings before a Subcommittee of the Committee on the Judiciary on $H$. R. 2318, 76th Cong., 1st Sess. (1939) 36, 119.

48. Id. at 138-139.

49. It has been estimated that from 1935 to 1939 the number of independent jobbers decreased from 15,000 to 9,000 . See $i d$. at 379 .

50. See TNEC Hearings at 8859 .

51. Hamilton, Price and Price Policies (1938) 124-140.

52. Difficulties in allocation of expenses and income for the processes of an integrated firm make it hard to assess the profitability of pipe lines relative to other branches of 
before the public, the majors, as might be expected in a market organized like the gasoline market, avoid price competition if possible. Instead each attempts to increase its share of the market by building up irrational consumer preferences for "Go-Gas", or for "No-Knox".:3 The companies have invested heavily in filling stations, which contributed in part to a wasteful overbuilding of retail outlets, ${ }^{54}$ and in branding and in advertising.5

Owners of non-company owned filling stations are often forced to deal exclusively in major company products ${ }^{50}$ partly because of the retailer's utter dependence upon the majors for his supply of gasoline. ${ }^{.7}$ This practice, known as full line forcing, is sometimes accompanied by major company control of retail prices, ${ }^{58}$ although there is evidence that the majors are relinquishing at least nominal control over policies of filling stations, both those not owned by them and those owned by them and leased to an operator. ${ }^{59}$

Control of the pipe lines now appears to be the nerve center of the oil empires, and the key to monopoly power in the industry. If the independent refiner could be given real access to the pipe lines, many elements of the majors' capacity to control prices throughout the petroleum industry would be eliminated. Almost certainly, there would be an increase in independentowned refineries in the market areas. ${ }^{60}$ This increase might talie some time, especially in view of the war situation, but, ultimately, it would probably come about. ${ }^{61}$ In addition, the present group of independent refiners located in the

the integrated companies. But there is some evidence indicating that "book" profits on pipe lines have been high in relation to returns from other parts of the integrated operation, and that therefore control of the pipelines is a vital factor in malsing profitable intsgration possible. See $i d$. at 130 ; Hearings before a Subcommittec of the Commitfec an the Iudiciary on $H . R$. 231S, 76th Cong., 1st Sess. (1939) 8.

53. Although the majors attempt to insulate demand for their product from the effects of price competition, the nature of the retail gasoline market prevents their efforts from being more than partially successful. For, due to the sensitivity of the marlict to small differences in retail prices, the independent retailer who is willing to cut prices can force other dealers in his competitive area to follow his downward price movement. See Hanilton, oṕ. cit. supra note 35 , at 117 et seq.

54. Id. at 129 .

55. Id. at 125; Lesar, Public Control of the Oil Industry (Unpublished thesis in the Yale Law School Library, 1937) 98.

56. See TNEC Hearings at $8731-8735$.

57. See TNEC Hearings at 8743 , for evidence as to the influence of this factor on full-line forcing.

58. See Hearings before Subcommittic No. 3 of the Commiltee on the Judiciary an H. R. 2318, 76th Cong., 1st Sess. (1939) 149, 152.

59. Hasinton, Price and Price Policies (1938) 139; Lesar, Public control of the Oil Industry (Unpublished thesis in the Yale Law School Library, 1937) 123 af scl.

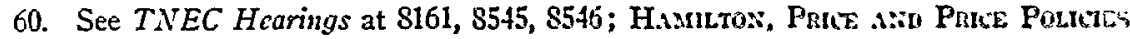
(1938) $150-151$.

61. It is, of course, possible that the small, independent retiner ean no longer compete with the major companies, due to the high costs of constructing a modern refinery. But, for evidence to the contrary, see TNEC Hearings at $\mathbf{8 5 4 5 .}$ 
field would be able to compete with the market-located refineries, by sending their gasoline to the major consuming areas via pipe line. Finally, the small group of independent refiners located in the market area could, by using the gasoline pipe lines, expand the area of their sales territory.

The consequent increase in competition from independent refiners should benefit the producer, who would have several buyers for his crude, insteacl of only one - the major owner of the pipeline outlet from his field - as is usually the case now. ${ }^{62}$ More important, this increase in refinery competition should produce a corresponding increase in competition in the marketing of gasoline. The price of gasoline to the jobber should decrease, as the independent refiner comes into the refinery market. The independent jobber, being able to buy gasoline from the independent refiner, would no longer be so completely dependent upon the major. Consequently, the jobber would be better able to retain his independent status and his freedom of action. Thus, prices to the dealer will tend to decline. At the retail level, increased competition from independent refiners should result in a decline in full-line forcing, and a decrease in the retail price of gasoline. The position of the independent service station dealer, who offers very effective price competition to the majors, ${ }^{63}$ would be bettered, as his sources of supply increase in number. Furthermore, real competition offered to the majors by independents might well force increased use of cost reducing technology. All of these changes would mean a substantial decrease in the price of gasoline to the consumer, ${ }^{64}$ in addition to helping thousands of independent businessmen retain a place in the petroleum industry. ${ }^{05}$

\section{Legal Technigues to Solve the Problem}

In an attempt to solve the pipe line problem, the United States brought suit against 20 major oil companies and 59 pipe line companies, comprising virtually all the important concerns. The suit was brought to enjoin further violations of those provisions of the Interstate Commerce Act ${ }^{60}$ and the

62. See testimony of Alfred M. Landon in Hearings before Committec on Interstate and Foreign Commerce on H. R. 16695, 71st Cong., 3d Sess. (1931) 59.

63. See Hearings before a Subcommittee of the Committec on the Judiciary on H. R. 2318, 76th Cong., 1st Sess. (1939) 222-223, 234, 311-312.

64. One estimate puts the decrease at 2c. per gallon. See TNEC Hearings at 7381.

65. The geographic extent of the effects of opening up the pipe lines is difficult to predict. Probably, the greatest effect would be in the midwest, the south, and the Rocky Mountain states. The effect on the Atlantic coast would not be great, since tankers, at least until the war, have played so large a role there. Lack of evidence as to the present accessibility of Pacific coast pipe lines to independent refiners makes prediction as to that region impossible.

An additional benefit of bringing pipe line rates more nearly into line with pipe line costs would be to make unitary operation of oil fields more effective. See Comment (1942) 51 Y YLE L. J. 608, 625.

66. 24 Stat. $379,380,381$ (1887) (as amended), 49 U. S. C. §6(7) (1940). 
Elkins Act ${ }^{67}$ which prohibit the granting or receiving of rebates from the rates of interstate common carriers. The Government also sought to collect triple the amount of rebates paid by the pipe lines to their oil company owners, as is provided by the Elkins Act. It seems evident that the pipe line companies and their oil company owners were violating the Acts. As has been shown above, the pipe lines have been paying large dividends to their owners. In effect, these dividends constituted rebates, since the oil companies would pay the full rates to their pipe lines, but would get back, in the form of dividends, a large part of the rates. In the light of the objective of the Acts ${ }^{68}$ of preventing commodities from being carried at less than the published rates, the device of dividend payments appears to come within their purview.

The result of the suit was a consent decree ${ }^{69}$ entered on December 23, $1941 .^{70}$ Under the major provision of the decree, governing distribution of earnings derived from common carrier services, no defendant common carrier pipe line ${ }^{71}$ shall pay during any one year to any of its shipper-owners more than $7 \%$ of the shipper-owner's share of the valuation of the common carrier's property - if the carrier has transported any oil or gasoline for the shipperowner during that year. The valuation of the carrier's property is that determined by the Interstate Commerce Commission plus any additions or betterments and minus depreciation and retirements. If a pipe line company earns more than $7 \%$ on its valuation, the excess is to be placed in a special surplus fund. By the terms of the decree, this surplus may be used for three purposes:

(1) To maintain normal and reasonable working capital;

(2) To retire any debt outstanding at the time of the entry of the decree, provided that such debt was originally incurred for the purpose of construction or acquisition of common carrier property; and

(3) To extend existing common carrier facilities or to construct or acquire new common carrier facilities. However, surplus spent for constructing or

67. 32 Stat. 847 (1903) as amended by the Hepburn Act, 34 Stat. 587-589 (1905), 49 U. S. C. $\$ 41(1940)$.

68. And as the Supreme Court has recently stated, results, not intentions determine whether these Acts have been violated. Union Pacific Railroad Co. v. United States, 313 U. S. 450,462 (1941). It could, however, be argued that since the Interstate Commerce Commission, which has the primary duty of enforcing these Acts, acquiesced in this practice of paying back rates in the form of dividends, the defendants did not knowingly violate the Acts, and hence were not guilty of a punishable violation. For a fuller discussion of the legal aspects of the suit see (1942) 9 U. of Cur. L. Rer. 503.

69. This was euphemistically called a "final judgment" at the request of the defendants. See Elkins Case Decree Will Limit Pipe-Line Profits (1941) 40 OnL A:D Gas Journal No. 33, p. 61.

70. United States v. Atlantic Refining Company, Civil Action 14060, (D. C. D. C.) (1941) (unreported).

71. This applies to several pipe lines which are operated as departments of oil companies, as well as to pipe lines which are operated as subsidiary companies of oil companies. 
acquiring new facilities cannot be included within the valuation upon which $7 \%$ of the earnings may be paid out; therefore, no earnings whatsoever can be paid out to shipper-owners on these new facilities.

Any defendant shipper-owner knowingly violating the terms of the decree may be fined three times the amount of the sum received as a rebate. ${ }^{72}$

The theory of the decree is that the desire of the oil companies to maximize their profits will result in a decrease in pipe line rates, and hence, permit independent refiners to make use of the lines. Although the excess earnings can be used for working capital and to pay off debts, these two outlets will be very small. ${ }^{33}$ In addition there probably will be little incentive to use this excess for the construction of new facilities, since no earnings whatsoever on new facilities can be paid out to shipper-owner oil companies. Thus, the theory runs, rather than let this surplus lie idle, and in order to avoid paying out for pipe line transportation excessive rates which cannot be paid back as dividends, the oil companies will lower the rates of their pipe line companies, thus lowering their own expenses for transportation ${ }^{74}$ It is hoped that the oil companies will elect to lower pipe line rates, in spite of the fact that the result will be to enable independent and competing refiners to use the lines.

However, it seems probable that the oil companies will elect to pay out these excessive rates to their pipe line subsidiaries or departments, rather than to invite more successful competition in all branches of the industry by lowering pipe line rates. The reason for this choice would be that unreturnable payments to the pipe lines will probably amount to much less than the loss in profits which would follow from an increase in competition from independent refiners. For, in 1939, the median figure of pipe line dividends as a percentage of net income for 13 major oil companies was $26 \%{ }^{75}$ That is, 26 cents of every dollar of net income was derived from pipe line opera-

72. The Government specifically reserved from this decree claims that it might have against any of the defendants in the pending suit against the American Petroleum Institute and the major oil companies and their subsidiaries, United States v. American Pce troleum Institute, Civil Action 8524, (D. C. D. C.) (1940). This suit was broughit in order to eliminate monopolistic practices in all phases of the petroleum industry and has been postponed pending conclusion of the war.

73. For figures indicating how small the debt of the pipe lines is, see Statistics of Oil Pipe Line Companies Reporting to the Interstate Commerce Commission for the Year Ended December 31,1941, I. C. C. Bureau of Statistics, Statement No. 4133 (1941).

74. Some support for this theory may be found. For, when the federal income tax law was changed to prohibit the filing of consolidated tax returns, which prevented the large profits on pipe lines from being merged in the losses or profits from other departments of the integrated major, pipe line rates were lowered, so gs to clecrease pipe linc profits and reduce taxes. See Reduced Pipe Line Rates and Gathering Charges, 243 I. C. C. 115, 139 (1940); Hasilton, op. cit. supra note 48, at p. 152, n. 1.

75. See Prewitt, The Operation and Regulation of Crude Oil and Gasoline Pipc Lines (1942) 56 Q. J. EcoN. 177, 179. In the entire petroleum industry oil and gasoline pipe lines constitute but $7.6 \%$ of the total amount of invested capital. See TNEC Hear" ings at 7701 . 
tions. Before the entry of the decree the pipe lines were making and paying out to their shipper-owners about $17 \%$ of their valuations. ${ }^{20}$ Under the decree they can pay out $7 \%$ as dividends, or about $40 \%(7 / 17)$ of the rate of return before the entry of the decree. $40 \%$ of $26 \%$ (the latter being the ratio of pipe line dividends to net income for the shipper-owners prior to the decree) is $10 \%$. This means that while the present ratio of pipe line dividends to net income for shipper-owners is $26 \%$, the consent decree will reduce this figure to $10 \%$. Thus, the decrease in oil company net income amounts to only $16 \%$. By reducing pipe line rates, the oil companies could recoup this $16 \%$. But, to reduce rates would be to permit small refiners to use the lines. By attempting to maintain net income at its present figure, competition will be increased, something which the major companies wuld not desire. In fact, the attempt to prevent a $16 \%$ loss could result in a loss of two or three times $16 \%$ as a result of competition in the market areas from independent refiners. Furthermore, the oil companies can afford to let the surplus lie idle in their pipe line companies for at least a few years. By the terms of the decree, the stockholders of the oil companies will receive this surplus if the pipe line company is ever dissolved. In the meantime, the oil companies can afford to wait, perhaps in the hope of some new development. Thus, from the standpoint of these considerations, the decree is likely to be ineffective. ${ }^{77}$ And, although nearly five months have elapsed since the signing of the decree, there have been no widespread reductions in pipe line rates. ${ }^{78}$

A prime defect of the decree is that the problem of service regulations, especially that of minimum tenders, is not dealt with at all. ${ }^{79}$ Another significant criticism of the decree is that the $7 \%$ return on value constitutes a large sum with which to fight competition. Or, put in another way, the sum amounts to a large rebate which oil companies will receive on their shipping charges. From the standpoint of law enforcement, the decree may well be said to countenance continued violation of the Interstate Commerce Act and the Elkins Act, albeit only a $7 \%$ violation.

76. See supra at 1341 .

77. It is reported that two attorneys in the Justice Department refused to sign the decree, and that one resigned from the Department. See Stone, Handcuffing Thurmas: Amold, (1942) 154 Natron 387, 388. Congressman John MI. Coffce, of Washington, has stated that the decree is inadequate, and has called for a Congressional investigation of the circumstances surrounding the decree. Communication to the YaLE Law Joun:BAL, May 20, 1942. See also 88 Cong. Rec., April 23, 1942, at 3791-3795.

78. Communication to the YALE LuW Jounn.1. May 26, 1942, from the Pipe Line Editor of the Oil and Gas Journal, which is a leading trade publication.

79. Mfinimum tender restrictions could have been attacked under the provisions of the Elkins Act prohibiting discriminatory practices. A minor defect of the decree is its limited scope. Some pipe line companies are not covered by the decree, but more importantly, future pipe line companies are not included. Perhaps, a threat to prosecute under the Elkins Act may be sufficient to induce entrance into the decree. 
There is also the possibility that the decree could be completely evaded by the pipe lines, through a reversion to private carrier status. This would have the additional advantage of freeing the lines from the regulatory powers of the Interstate Commerce Commission. Such a move is, however, beset with difficulties, particularly in view of the attitude of the United States Supreme Court, as reflected in the Valvoline Oil Company case. ${ }^{80}$ The Court held in that case that an oil company owning and operating a pipe line through which it transports to its own refineries, partly across state lines, oil which it purchases from producers in the oil fields, is nevertheless a common carrier within the meaning of the Interstate Commerce Act. Such a company may constitutionally be required to furnish information to the Interstate Commerce Commission for use in valuing the company's properties. The Court did not pass upon the question of whether the Commission could regulate the rates and practices of such a company, but the tenor of the opinion, and the record of the present Court, would indicate that reversion to private carrier status would not be approved by the Supreme Court. ${ }^{\text {a1 }}$

Other legal techniques for opening up the pipe lines are available. Regulation by the Interstate Commerce Commission could be more effective than it is, if the Commission were to exercise the wicle powers over pipe lines given it by the Hepburn Act, ${ }^{82}$ and sustained by the United States Supreme Court in the Pipe Line Cases. ${ }^{83}$ This power, in the words of the Commission itself, extends to "the legality and lawfulness of each and all rates, charges. rules, regulations, and practices" of interstate common carrier oil and gasoline pipe lines. ${ }^{84}$ From 1914, when the Pipe Line Cases were decided, down to 1934 , the Commission did very little in the way of regulating pipe line rates and practices. In 1934, the Commission began an investigation into the rates and practices of crude oil pipe lines, which has not yet been concluded. In pursuance of this investigation, the Commission in December, 1940, issued an order to a large group of the oil pipe line companies to show cause why their rates should not be reduced so as to produce a net return of $8 \%$ on value, and why their minimum tender requirements should not be reduced to 10,000 barrels. $^{85}$ Further hearings have been held since this show cause

80. Valvoline Oil Company v. United States, 308 U. S. 141 (1939). See also the Pipe Line Cases, 234 U. S. 548 (1914).

81. A further possibility might be voluntary divorcement of the pipe line propertics from other interests of the major companies. For example, a major company might transfer all the stock of its pipe line subsidiary to its own stockholders. These stockholders could control the pipe line company in the interests of their larger investments in the oil company by maintaining rates at a high level, thus preventing independents from using the lines. In addition, all the earnings of the pipe line, not just the $7 \%$ allowed by the decree, could be paid out, since they would not go to any shipper-owner. Such a scheme might face some difficulties, but it is a possibility to be considered.

82. 34 Stat. 584 (1906), 49 U. S. C. $\$ 1$ (1940).

83. 234 U. S. 548 (1914).

84. Reduced Pipe Line Rates and Gathering Charges, 243 I. C. C. 115, 117 (1940).

85. Reduted Pipe Line Rates and Gathering Charges, 243 I. C. C. 115 (1940). 
order was issued, but after $S$ years of investigation, the Commission has yet to issue a final order. ${ }^{86}$ However, there have been some rate reductions made since the show cause order was issued. $\$ 7$

In the case of Petroleum Rail Shippers Association a'. Alton \& Southern Railroad, ${ }^{88}$ the Commission ordered substantial rate reductions and an atjustment of minimum tender restrictions for two gasoline pipe lines in the mid-western area. The lines concerned were those of the Great Lakes Pipe Line Company and the Phillips Petroleum Company, and these lines run from the Mid-Continent oil producing area (Kansas, Oklahoma, and northern Texas) to the large cities in the midwestern states. The extent of the reluitions in rates can be gathered from the following table, which compares former rates with the newly ordered rates for the Great Lakes Pipe Line Company..$^{\text {s9 }}$

\begin{tabular}{|c|c|c|}
\hline From the midcontinent area to: & $\begin{array}{l}\text { Former rate } \\
\text { in c. per } 100 \text { lbs. }\end{array}$ & $\begin{array}{c}\text { Newrale } \\
\text { in e. per } 100 \text { lits }\end{array}$ \\
\hline Kansas City, Mro.-Kan. $\ldots \ldots \ldots \ldots \ldots \ldots \ldots$ & 28 & 10 \\
\hline Des MIoines, Iowa ........ & 36 & 13 \\
\hline Omaha, Neb. ......................... & 36 & 15 \\
\hline Chicago, Ill. ......................... & 40 & 24 \\
\hline Minneapolis, Minn. ..................... & 46 & 21 \\
\hline
\end{tabular}

The adjustment of minimum tender restrictions was of a less drastic character.$^{30}$ The order has proved of substantial benefit to the large group of independent refiners located in the midcontinent producing area, who are now better able to market their gasoline in the great marketing areas. 01 The decision takes on added significance since the largest group of independent refiners is located in the midcontinent field.

Another technique which might be employed to open the pipe lines to independent refiners is the compulsory divorcement of pipe lines from the oil companies which own them. Proponents of divorcement advance several arguments for their plan. Thus, if the ownership of pipe lines is taken away from major oil companies or major oil company stockholders, and placed in

86. It is possible that a lack of sufficient funds has been responsible for the delay in issuing a final order.

87. Communication to the Yale Law Jourand, Mfay 26, 1942, from Pipe Line Editor of the Oil and Gas Journal, one of the leading trade publications.

88. 243 I. C. C. 589 (1941).

89. See id. at 616 and 665 .

90. See $i d$. at 665 . The Commission ordered that the pipe line companies accept for transportation, subject to delay until the companies have accumulated at that receiving point 25,000 barrels of the same specifications from the same or other shippers, shipments as low as 5,000 barrels. But, the time during which such small shipments are stored at origin shall be deducted from the storage time now allowed at destination. Formerly, the companies would accept for shipment only tenders which were from one shipper, and which amounted to at least 25,000 barrels.

91. Communication to the Yale Law Jouranal, May 2, 1942, from Traftic Mianager of the El Dorado Refining Company, El Dorado, Kansas. 
the hands of persons having no interests in the oil business, the pipe lines should become more readily accessible to small shippers. Independent pipe line companies, desiring only to maximize profits on the pipe line business, would lower rates and eliminate repressive service regulations, with a view towards getting the greatest possible amount of business away from the tankers and the tank' cars. Rates and regulations would no longer be adjusted with a view towards permitting the major company to buy crude oil at favorable prices and preventing small shippers from using the lines; instead, precisely the opposite viewpoint would prevail. Furthermore, it is contended that divorcement would mean that the major oil companies would no longer enjoy the large return on their investment in pipe line properties. Even 7\% or $8 \%$ of an investment of several hundred million dollars is a powerful club in the competitive struggle..$^{22}$ Terminating control over the pipe line rates, which permits the majors to fix the prices at which they buy oil and sell gasoline, should substantially reduce their power to buy cheap and sell dear. Divorcement is probably the only step which might permit the achievement of more competition in the petroleum industry, and of the economic and social objectives which animate the case for more competition.

On the other side of the ledger there are several objections to divorcement. Conceivably, it might be difficult to market so vast a volume of securities. However, one suspects that the liberal attitude of the Interstate Commerce Commission towards profits, which was manifest even in the Petroleum Rail Shippers' Association case, ${ }^{93}$ would induce buyers to invest money in such a profitable venture. A similar point made is that unless the refiners

92. In 1935, the valuation of a very large percentage of oil pipe line mileage amounted to over 450 million dollars, according to I. C. C. figures. See Reduced Pipe Line Rates and Gathering Charges, 243 I. C. C. 115, 148 (1940). On the other hand, it should not be forgotten that the oil companies could invest the proceeds from the sale of their pipe line properties in other industries, such as synthetic rubber, plastics, or others. Perhaps it would not be as easy to make 7 or $8 \%$ in these industries as in pipe lines, but some profit could be made, and this profit could be used as a weapon in the struggle for domination of the oil industry.

The National Recovery Act authorized the President to institute proceedings to divorce pipe lines from holding companies whenever unfair practices or exorbitant rates tended to create a monopoly. 48 Stat. 200 (1933), 15 U. S. C. $\$ 709$ (b) (1934). Proponents of divorcement base its validity on the analogous separation of the railronds from their coal interests by the Hepburn Act, 34 Stat. 585 (1906), 49 U. S. C. $\$ 1(8)$ (1940), and the divorcement of the meat packers from their retail outlets. Swift \& Co. v. United States, 276 U. S. 311, 328 (1928). See 6 TNEC, Verbatim Recordos of ProCEEDINGs (1939) 128, 255-59, 262; Hearings before Subcommittee No. 3, Judiciary Committee, on H. R. 2318, 76th Cong., 1st Sess. (1939) 91-95; United States v. Columbia Gas \& Electric Corp., Tege Federal Antitrust Laws (1938) 260 (consent decree divesting companies of their control of natural gas pipe line).

93. For example, the cost of shipping 100 pounds of gasoline from Tulsa, Oklahoma, to Chicago plus a profit of $10 \%$ on the value of carrier property amounts to $20 \mathrm{c}$., while the rate set by the Commission in this proceeding was $24 \mathrm{c}$. Other rates set were comparable to this in the matter of large profits being allowed. See Petroleum Rail Shippers Association v. Alton and Southern R. R., 243 I. C. C. 589, 663, 665 (1941). 
own the pipe lines, new pipe lines to new fields will not be rapidly constructed, thus harming the small producer. A mere transportation company, having no assured refinery outlet, might hesitate to expend funds for new facilitics. This argument, however, overlooks the facts that refineries, whether they own pipe lines or not, are interested in new sources of supply, and would be willing to promise a certain amount of business to the pipe line company, if the new line is built. If there is a real demand for transportation service, that demand presumably would be met. As a corollary to the above, it is said that the small producer would suffer from divorcement, since divorcement would result in the abandonment of pipe line service to fields whicin are nearly exhausted, or to fields which are no longer profitable to drill bscause of the discovery of better fields elsewhere. If the oil companies owned the pipe lines, so the argument runs, pipe line service would be continued in order to maintain a reserve of crude. However, if the production of at field can no longer justify its use from an economic standpoint, that field should not be subsidized by the maintenance of transportation service.

Opponents of divorcement argue that large savings result from integrated operation. But operation of pipe lines as separate companies with their own managements ${ }^{94}$ and required to show separate profits probably will not increase pipe line costs. For pipe lines today have managements, and divorcement should not mean an increase in personnel. And as long as the independent pipe line companies compete or are properly regulated by administrative control, their charges should presumably be just sufficient to cover costs and a fair return on investment - which were necessary costs when the pipe line was part of an integrated firm. On the contrary, reduction of pipe line costs should result from horizontal rather than vertical combination; and such horizontal integration could be gained by selling the divorced lines to large pipe line corporations operating many thousands of miles of pipe lines. Nor is it of any weight that integrated operation gives a business unit of larger size. ${ }^{95}$ For there is no reason to believe that modern corporate enterprises are of the optimum size from the standpoint of technology since they were created by financiers because of quite different considerations. However, perhaps the close coordination possible under the existing arrangement does result in lower production or refinery costs than would be the case under divorcement. But against this possible advantage must be placed the disadvantage of the monopolistic elements existing at present in the industry. For now the integrated major, by maintaining a high profit margin on its pipe lines, can force the non-integrated producer to sell to him at what is usually a non-competitive price and can also place the non-integrated refiner at a competitive disadvantage in marketing his products in important consuming areas. ${ }^{90}$

It is true that mere divorcement might not result in lowering rates and eliminating burdensome service regulations. For pipe lines in some areas

94. See Beard, op. cit. supra note 26 , at 122.

95. Stigler, The Extent and Bases of Monopoly (June, 1942) 32 An. Eoo:. Rev. 1,8.

96. Id. at 22. See generally, Buzws, Decime of Cosrpetition (1936) 431 ot seq. 
occupy a monopolistic position. For example, water transportation is unavailable in many areas, and railroad tank car rates are too high to offer the pipe lines real competition. If there is only one pipe line in the area, or if two or more pipe lines "cooperate," rates could be maintained at a level much above costs. It is also conceivable that the superior bargaining position of the major oil companies might influence the pipe line companies to discriminate against small shippers in the matter of service regulations. In short, divorcement is not utopia, and there would still be a need for regulation.

If divorcement is utilized as a method of solving the problem, several techniques of achieving it are available. The government might ask for divorcement in the pending anti-trust suit against the American Petroleum Institute and the major oil companies.97 Divorcement might also be secured by litigation based on those sections of the Interstate Commerce Act and the Elkins Act which prohibit rebates. ${ }^{98}$ Congressional legislation would also be an effective method of bringing about divorcement. The Commodities Clause of the Hepburn Act ${ }^{90}$ could be applied to pipe lines. ${ }^{100}$ As presently worded, the Commodities Clause, with minor exceptions, forbids railroads from carrying goods which they own or in which they have an interest. There is considerable doubt as to whether the clause, as presently worded, would apply to situations like that prevailing in the petroleum industry, where the manufacturer controls the carrier, instead of the opposite being the case. ${ }^{101}$ A mere change of wording would, of course, make clear that no oil company could ship petroleum or petroleum products over a pipe line which it owned in whole, or in part. ${ }^{102}$ If the Commodities Clause were applied to pipe lines, the oil companies would be forced to sell their pipe line properties, or go out of another branch of the industry. In order to prevent evasion of the purpose of divorcement, administrative control of the divorcement process should, perhaps, be provided.

There are additional solutions to the pipe line problem each of which can be but briefly mentioned. Conceivably, a new government regulatory agency could be set up to regulate the lines. Perhaps a new agency, charged directly with regulating pipe lines, would be more aggressive in eliminating the pres-

97. United States v. American Petroleum Institute, Civil Action 8524, (D. C. D. C.) (1940).

98. For an able treatment of divorcement by litigation see Black, Oil Pipe Line Divorcement by Litigation and Legislation (1940) 25 CoRN. L. Q. 510.

99. 34 Stat. 584, 585 (1906), 49 U. S. C. $\$ 1(8)$ (1940).

100. While the Hepburn Bill was before the Senate for consideration, Senator Elkins offered an amendment which would have applied the Commodities Clause to all common carriers. However, as finally passed by Congress, the Commodities Clause was applied only to railroads and excluded pipe lines. Since that time, there have been numerous bills introduced in Congress to apply the Clause to pipe lines. See Black, supra note 98, at 533 .

101. See $i d$. at $532-533$.

102. See $i d$. at 533-536 for an excellent discussion of legislation which would effectively apply the Commodities Clause to pipe lines. 
ent abuses in pipe line operations. Among the many objections to this proposal, perhaps the chief one would be that it would result in a lack of coordinated treatment of the whole of the transportation problem. There would be another agency added to the number now engaged in regulating transportation. Such a plan would be especially open to this criticism now in view of the critical situation in oil and gasoline transportation.

Possibly, government ownership and operation would be effective. Such direct governmental participation should be on a limited scale, following the TVA or yardstick principle, at least initially. For there would be no need, for example, to take over all the crude lines running from the mid-continent area to the Chicago area. If one were governmentally owned and operated, it might be sufficient to handle all the oil that independent refiners might care to ship. In addition, such competition might -also result in reduced rates for competing lines. Finally, it might well serve as a warning to pipe lines in other areas that abuses must end. An encouraging step in governmental ownership is the gigantic new crude line now being built from east Texas to Norris City, Illinois. Although this line, the world's largest, is to be operated by the War Emergency Pipe Line, Ine., a corporation formed by several majors, it is to be owned by the Defense 'Plants Corporation, a subsidiary of the Reconstruction Finance Corporation. If, as proposed, this line is extended to the Eastern coast, governmental ownership should again be provided. But, it should be remembered that government ownership alone may be of little value. A strict policy of control, if not actual operation, is essential if the abuses in pipe line operation are not to occur in the managing of this particular line.

The plan has also been proposed that pipe lines be treated not as common carriers, but as plant facilities in an integrated industry. If pipe lines were given this status, the whole of the oil industry might be given the status of a public utility, and regulated as a single unit. It is contended that all the economies of integration could be realized, while strict government control of the entire industry would prevent abuses. ${ }^{103}$ Such a proposal raises questions beyond the scope of this article, since it concerns the complex problems of oil production, oil refining, and the marketing of petroleum products. However, it is possible that the economies of integration have received undue emphasis. In addition, competition should be given a further chance to demonstrate its effects, before such a far-reaching proposal is adopted. If the pipe lines could be made real common carriers, competitive conditions might be restored in large measure, thus obviating the necessity of the regulation of the entire industry.

\section{ConcLUSION}

The aim of this Comment has been to examine the pipe line problem, and to indicate possible lines of advance, rather than to draw any final con-

103. See BEARD, op. cit. supra note 26 , for a discussion of this plan. 